\section{CIHM}

Microfiche

Series

(Monographs)
ICMH

Collection de microfiches (monographies)

Canadian Institute for Historical Microreproductions / Institut cesnadien de microreproductions historiques
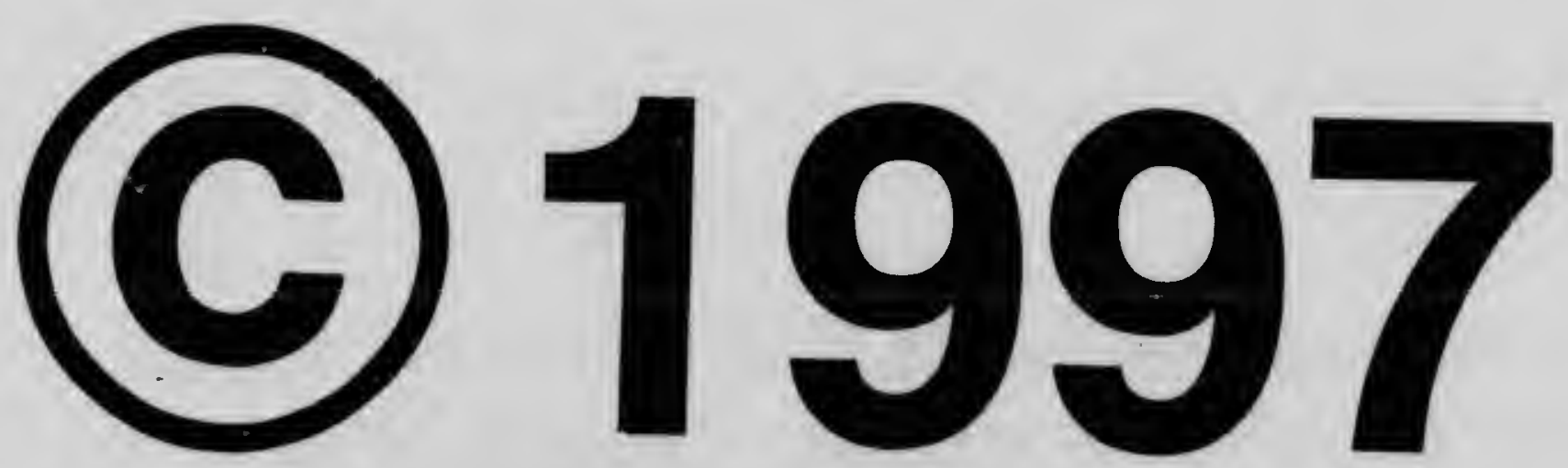


\section{Technical and Bibliographic Notes / Notes techniques et bibliographiques}

The Institute has attempted to obtaln the best original copy avallable for filming. Features of thls copy which may be blbllographically unlque, which may alter any of the Images In the reproduction, or whlch may slgnificantly change the usual method of fllming are checked below.

\section{Coloured covers /}

Couverture de couleur

Covers damaged /

Couverture endommagee

Covers restored and/or laminated /

Couverture restaurée etou peiliculé

Cover titie missing / Le titre de couverture manque

Coioured maps / Cartes géographlques en couleur

Coloured ink (i.e. other than blue or black) /

Encre de couleur (l.e. autre que bieue ou nolre)

Coioured piates and/or lilustrations /

Planches et/ou lilustrations en couieur

Bound with other materiai /

Relié avice d'autres documents

Only edition available /

Sevie édition disponibie

Tight binding may cause shadows or distortion along interior margin / La reliure serrée peut causer de l'ombre ou de ia distorsion le long de la marge intérieure.

Biank leaves added during restorations may appear within the text. Whenever possibie, these have been omitted from fiiming / II se peut que certaines pages blanches ajoutées iors d'une restauration apparalssent dans le texte, mais, iorsque ceia était possibie, ces pages n'ont pas été filmées.

Additional comments /

Commentaires supplémentaires:
L'institut a microfilmé ie meilleur exemplaire qu'li lul a été possible de se procurer. Les détalls de cet exemplalre qul sont peut-etre uniques du polnt de vue blbllographlque, qul peuvent modifier une image reprodulte, ou qul peuvent exiger une modification dans ia méthode normale de filmage sont Indlqués ci-dessous.

\section{Coloured pages / Pages de couleur}

Pages damaged / Pages endommages

Pages restored and/or laminated /

Pages restaurées et/ou peiliculées

Pages discoioured, stained or foxed /

Pages décoiorées, tachetées ou piquées

Pages detached / Pages Jótachées

Showthrough / Transparence

Quality of print varies /

Qualité inégaie de l'Impression

Inciudes supplementary materiai /

Comprend du matériei suppiémentaire

Pages wholly or partially obscured by errata slips, tissues, etc., have been refiimed to ensure the best possible image / Les pages totaiement ou partiellement obscurcies par un feuiliet d'errata, une pelure, etc., ont été filmées à nouveau de façon à obtenir la meilieure image possible.

Opposing pages with varying colouration or discolourations are filmed twice to ensure the best possible image / Les pages s'opposant ayant des colorations variables ou des décolorations sont filmées deux fois afin d'obtenir la meilleure image possible.

This hem is filmod at the reduction ratio cheeked below I

Ce document cet films au taux de riduction Indiqus ofebesous.

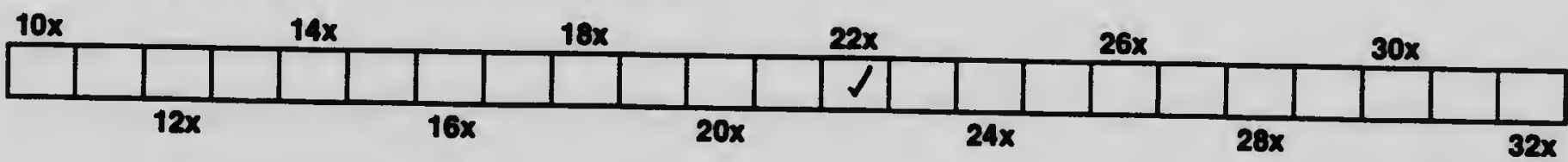


The copy filmed here has been reproduced thanks to the generosity of:

\section{Library \\ Agrieuhure Congde}

The images appearing here ore the best quality possibie considering the condition end legibility of the original copy and in keoping with the filming contract specificetions.

Original coples in printed paper covers ore flimed baginning with the front cover end onding on the lest page with a printed or illustreted impres. sion, or the back cover whon eppropriate. All other original copies are flimed beginning on the first pege with a printed or lliustroted impres. sion, and ending on the lost pege with e printed or lliustrotod impression.

The last recorded frame on each microfiche shail contain the symbol $\rightarrow$ Imeoning "CON. TINUED"), or the symbol $\nabla$ (meaning "END"). whichover applies.

Mops, plates, charts, otc., moy be flimed at difforent rediction ratios. Those too lerge to be entirely included in oné exposure ore filmed beginning in the uppor loft hand corner, ioft to right and top to bottom, as meny frames es required. The following diegrams illustrote the mothod:
L'exempleire fllmb fut reproduit gráce d lo óndroaltó de:

\section{Bibliothique \\ Apriculture Canada}

Les imeges suiventes ont btd roproduites avec it pius grend soin, compto tenu de is condition ot do ie nottots de lexomplaire films, ot en conformits evec les conditions du contrat de flimego.

Les exempiaires originaux dont is couvorture on popier est imprimb́ sont flimb́s en commençent par io premior piot at en torminont soit par be dernibre page quil comporte une empreinte dimpression ou dilliustrotion, soit per it second piet, seion is cos. Tous ies eutres exempiaires originoux sont filmbs en commencent per lo premidre page qui comporte une emprointe d'impression ou d'iliustration ot en terminont par ie dernilare page qui comporte une tolle emprointe.

Un des symbolos sulvants epparottra sur la dernidre image de chaque microficho, solon ie cas: lo symbole $\rightarrow$ signifis "A SUIVRE", io symboie $\nabla$ signifie "Fin".

Les cartes, plenches, tablooux, otc., peuvent Stre flimbs a dos taux do réduction diffirents. Lorsque ie document est trop grand pour stre reprodult on un soul clichs, if eat filmo a partir de l'angie supbriour geuche, do gouche s drolte. ot de haut en bas, on prenent io nombre d"imeges nuceseaire. Les diagrammes sulvents ililustrent in mothode.
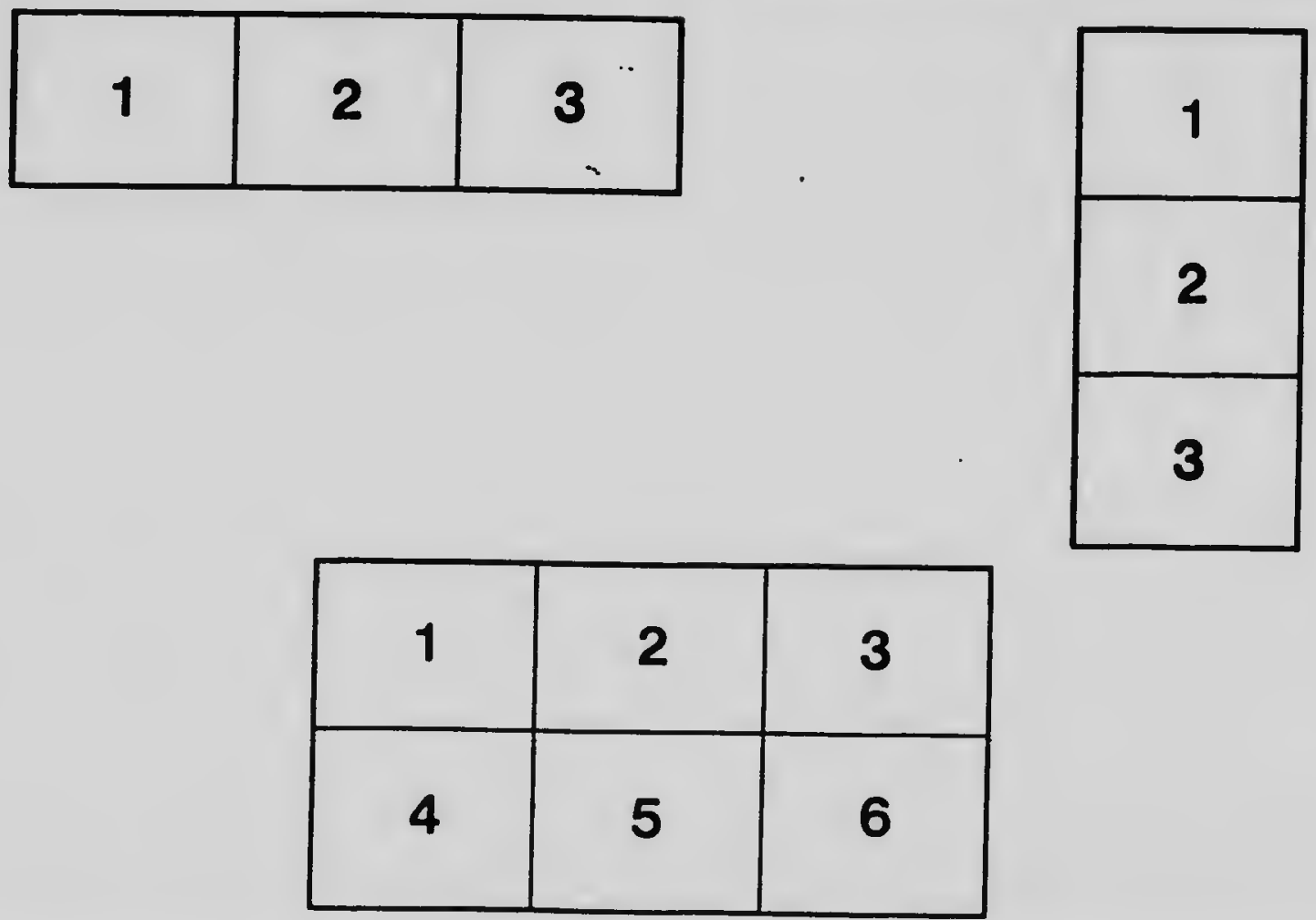


\section{Manocont nesowtion TEST CHAMt}

(ANSI and ISO TEST CHART No. 2)
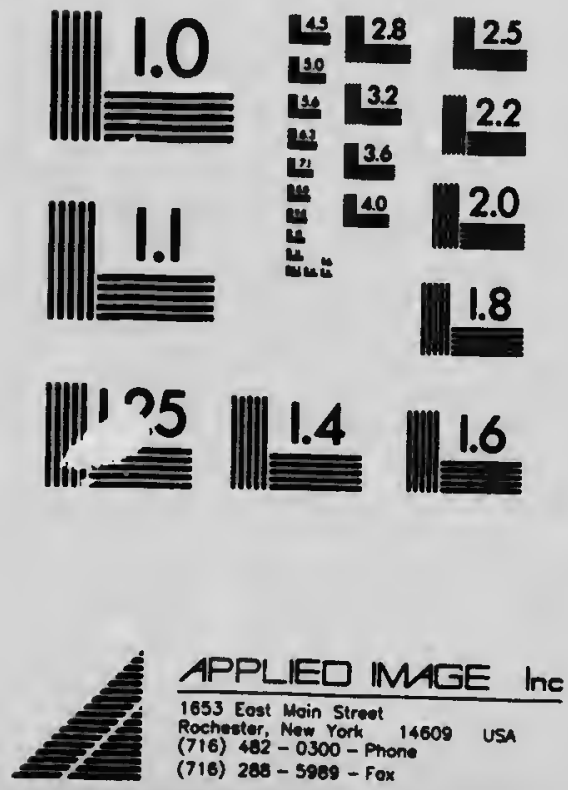


\title{
AN EXPERIMENTAL SHIPMENT OF FRUIT TO WINNIPEG.
}

\author{
By J. B. Reyulud, Professor of Physics.
}

\section{SUMMARY.}

1. The Western market demands well-co'ored and well-matured fruit.

2. Both in appearance and in prices, Ontario peaches, if allowed to mature properly on the tree, compare favorably with California peaches on the Wilinipeg market.

3. California and British Columbia, although at a much greater distance than Ontario, are fast gutting a monopoly of the Western market.

4. Owing to tariff and higher freight charges, California peaches, in competition with Ontario peaches, suffer a handicap of 40 cents a box.

5. In carload lots, freight rates to Winnipeg, including icing, are little more than one-third express rates. Quickly-ripening fruit is safer in a good refrigerator car for six or eight days than in a hot unventilated express car for three days.

6. Transportation ought to be no hindrance to a large expansion of trade in tender fruits between Ontario and the Northwest. Peaches, plums, grapes, and Bartlett pears, well matured, carried safely with eight days' transit. A transit of five days over the same route is frequently accomplished, and is quite practicable.

7. Our fruit is at a disadvantage in the market because of the general lack of uniformity, neatness, and skill displayed in grading and packing.

8. A uniform size and style of package is very desirable. So far as possible, all box packages should be of the same length and width, and should vary in depth to suit the character of the fruit.

9. So far as rapid cooling and safe shipping in cold storage are concerned, the barrel is suited to winter apples, the bushel box, $10 \times 11 \times 20$ inches, to early fall apples and winter pears, and the half bushel $5 \times 11 \times 20$ inches, to peaches and early pears.

10. The basket carries grapes and plums satisfactorily, but, for safety, it should be enclosed, as in the Georgia 5-basket carrier, Fig. 4, or the 2-basket carrier, Fig. 8.

11. To remedy existing defects in all c partments of the fruit trade, and to put it on a secure footing, the co-operative plan should be adopted, including a central packing house, the employment of expert packers, and an organization capable of overcoming obstacles. 


\section{PRELIMINARY ARRANGEMENTS.}

(1). In the summer of 1903 the writer, after making some extended inquiries into the matter of transportation of fruit under refrigeration, recommended to the Minister of Agriculture an experimental shipment of fruit from Southern Ontario to the Nolthwest of Canada, with a view to obtaining information on the whole question of the Westetn fruit trade. The situation with respect to this trade, though it should be full of hope, is as a matter of fact discouraging to the Ontario fruit-grower. On the one hand, as an enticing prospect, there lies the great Northwest, a large, increasing, and ever profitable matket. The choice fruits peculiar to Southern Ontario will never be produced in those northern latitudes, and an exchange of Ontario fruits for No. 1 hard wheat seems reasonable and proper. On the other hand, as a discouraging reality, fruits from the Pacific Coast are rapidly pre-empting the Western market, and rarely can Ontario peaches, grapes, and plums be seen displayed in the shopfronts of Winnipeg. Very little fruit, if any, except apples and pears, is being shipped to the West by freight, and express charges are almost prohibitive. Prominent and well informed fruit growers, who have done some shipping on their own account, upon being consulted on this matter, gave the opinion that, for several reasons, a freight traffic in tender fruits between Ontario and the Northwest was impracticable. The reasons E ven are, in the main as follows : First, our fruits are not of good shipping quality; secondly, the railroads do not give sufficiently rapid despatch: thirdly, in refrigerator cars, icing is not properly attended to in transit; fourthly, the market, and the means of disposing of the fruit in the West, are uncertain.

With respect to the first of these objections, namely, the poor shipping quality of our tender fruits, the force of the objection remained to be tested by an actual shipping experiment. In the meantime, storage experiments conducted at the College had demonstrated that Crawford peaches will hold their form and quality for eighteen days at a temperature of 38 degrees; peaches of the Longhurst type will keep sound and firm for thirtysix days, and Washington and Bradshaw plums for twenty days, at the same temperature. It is generally supposed, however, that fruits do not keep so well during shipping as they do in the warehouse, by reason of the injuries incident to transportation. At the same time, careful packing and loading in carload lots not to be rehandled during transit, would, it was believed, reduce to a minimum the damage incurred in shipping.

The remaining objectiuns, namely, those relating to time of transit, icing, and the market, while undoubtedly serious, are not insurmountable, and relate to conditions capable of improvement and correction. It was the aim of the proposed experiment to secure information upon these very points, and to bring such matters as require righting to the attention of authorities competent to deal with them.

Early in the season of 1904 , with the approval of the Minister, active preparations for this shipment were commenced. Much preliminary work had to be covered before the shipment could be undertaken, such as decid- 
ing upon and obtaining the packages to be us

uterviewing fruit growers and securing promises of contributions to the shipment, instructing them upon the selection and packing of the fruit, and arranging the terms upon which the fruit was to be supplied. Before hand, certain conditions seemed without trial to be essential to success, and these were as far as possible closely adhered to: the fruit selected should be all No. 1 grade, and should be sufficiently mature to be of good quality upon reaching the market : peaches and Bartlett pears should be wrapped singly in paper ; closed packages only should be used; the cars should be loaded carefully by nailing each package in place, and by spacing packages so as tn allow circulation of air on all sides of a package; by shipping in carload lots the fruit would not be rehandled until it reached the market; and the cars must be kept iced, and as quick transit as possible secured. Crawford peaches formed the staple variety in the shipment, and as many kinds of fruit as were in season at the same time were included. Owing to the lateness of fruit this year, the cars were not shipped until September 14 th and 16 th respectively:

(2). From St. Catharines was sent a C. P. R. car, Bohn refrigerator system, and from (irimsby a car known as the Hanrahan refrigerator. These two cars differ in their interior construction in four particulars: First, the ice bunkers in the Bohn system are at the ends of the car; in the Hanrahan the ice is in the middle of the car: second, in the Hanrahan, horizontal flues the full width of the car run just below the ceiling from the ice bunkers in both directions to the ends of the car, for the purpose of

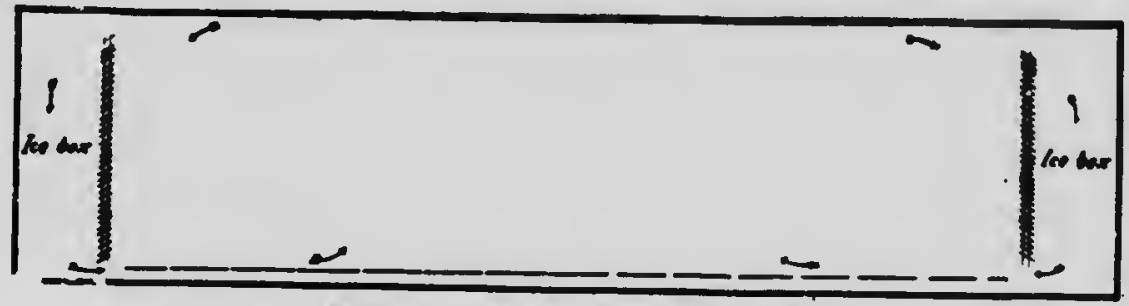

Bection of C.P.R. car ; Bohn refrimerator.

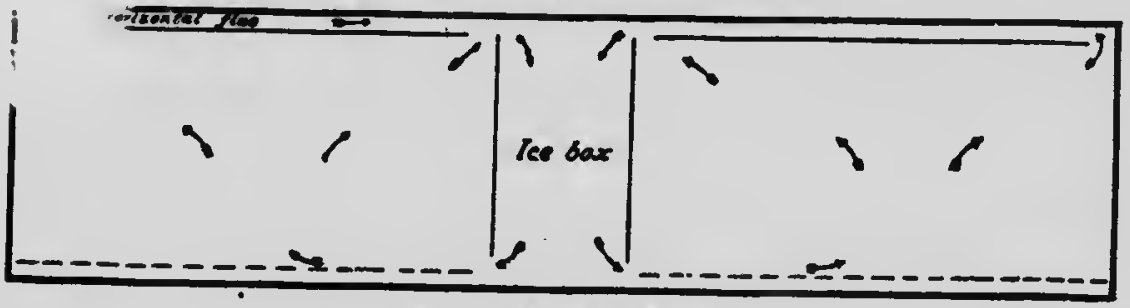

Section of Hanrahan car.

Fig. 1.

conveying to the bunkers the warm air from the ends remote from the ice and allowing cold air to flow back to these ends; in the Bohn system there is no such flue. Third, the floor of the Hanrahan is provided with a rack, like lattice work, that carries the load off the floor and allows air to flow underneath; the floor of the Bohn system is provided only with slats two inches high and about eight inches apart running lengthwise of the 
car. These slats are not suitable for loading boxes. The fourth difference consists in the form of partition between the ice bunker and the car proper. In both cases there are spaces above and below the partition providing for the flow of warm and cold air. But in the Hanrahan the partition, with the exception of these spaces, is solid, and thus gives definite direction th the air currents. In the Bohn system the partition is formed of gal. vanized iron slats, placed like the slats in a window shutter. Sertiuns of the cars are shown in Fig. 1 , and illustrate these differences.

It was expected that $n$ transit of six or eight days with plums and Crawford peaches would indicate any difierence: in efficiency between the cars. It is claimed that some refrigerator cars fail to maintain a uniform temperature throughout the car-the top of the car and the parts most remote from the ice, being, it is claimed, several degrees higher in tempera. ture than the bottom near the ice. This difference of temperature would of crurse be most pronounced in hot weather, and in cool weather would be small. It so happened that the weather during this shipment was quite cool. Whether or not this fact accounts for the uniformity in results cannot be asserted, but at all events there was no notigeable difference in the condition of the fruit upon arrival a Winnipeg. As a test of efficiency in the cars, therefore, the experiment is inconclusive, and must be repeated in warmer weather or over greater distances, before any decisive report can be given out upon this matter.

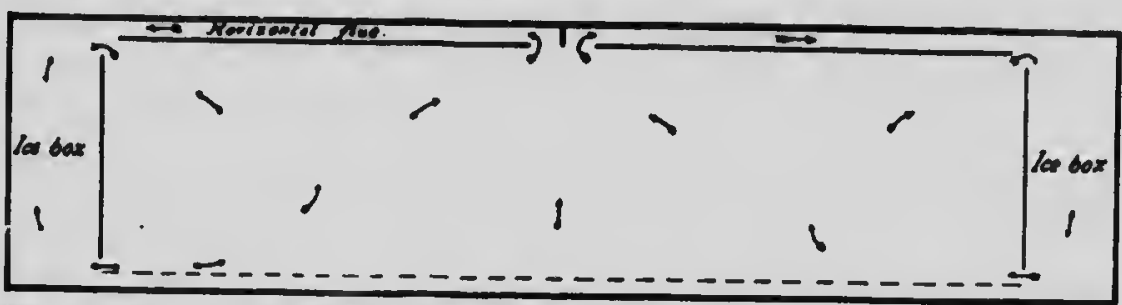

Fig. 2 - Sectlon of car showing interlor construction for alr circulation with bunkers at end. The molid partiflin wext $w$ the lee and the norizontal fue overhead will, it is believed, Improve the
efflelelcy of refrigerator cars.

To maintain uniformity of temperature throughout a refrigerator it has been already demonstrated beyond question that a regular circulation of air through the whole system, including refrigerater and ice-house; is necessary. To secure circulation the construction of the refrigerator must be such as to give direction to the air. In principle, and in practice where the test is sufficiently severe, the Bohn system may be improved by adopting the essential parts of the Hanrahan system where this relates to air circulation: that is, a solid instead of a slatted partition, and a flue overhead, (Fig. 2). 


\section{I1. OBSERVATIONS AT THE SHIPPING POINT.}

By l'kor. H. I. Hutt, Hokticultukist, Ontakio dikicultukal College.

(1) TuE. Fevit. Among the objects of this shipment, one was to place on the Winnipeg market some of the choicest fruit that Ontario could produce, in the hope of helping to opent a trade for Ontario growers in the great Northwest.

The accompanying tables give in a condensed form most of the particulars regarding the class, variety, grade, and condition of th? fruit shipped. While much of the fruit in each car was first-class, or graded SXX, some of it, as :te recurds show, fell much below that grade, and certainly would not have been shipped if sulficient firstoclass fruit had reen obtainable at the time. The growers were handieapped in this respect to some extent by the unusual inteness of the season, and also by the light crop of some classes of fruit, pirticulirly of the peaches and plums, which we were especially desirous of including in the shipment.

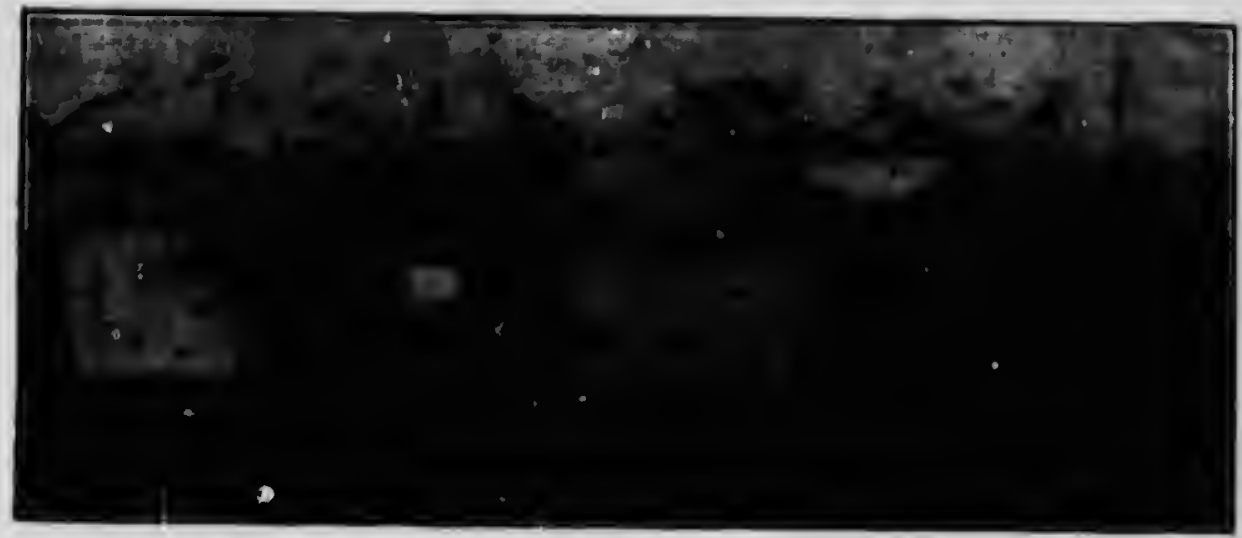

Fig. 3.-Some Ontario Apple Boxes :

1. Dimensions, 9 in. $\times 12$ in. $\times 10$ in ; capacity, 2137 cubic inches.

2. Dim. ons, 9 in. $\times 13$ in. $\times 18$ in. ; capacity, 2106 cuhic inches.

3. Di ons, $99 \mathrm{in} . \times 14$ in. $\times 201$ in.; capacity, 2764 cubic inches.

4. Dinieusions, 10 in. $\times 10$ in. $\times 221$ in.; capacity, 2225 cubic inches.

5. Dimensions, 11 in. $x 111$ in. $x 221$ in.; capacity, 2784 cubic inches. inches.

The standard size (not shown), 10 in. $x 11$ in. $x 20$ in.; capacity, 2200 cubic

Another reason that much of the fruit was not of $a$ kind to tempt the buyer was because it was picked too green. A general impression seemed to be in the minds of many of the shippers that none but green, hard fruit, particularly of peaches, plums, and pears, would carry safely to the Winnipeg market. 'This was, of course, a point upon which no reliable information was at hand, and one of the valuable lessons afforded by thi.: experiment is tha: our finer fruit, such as peaches, plums, and pears. should at the time of shipment be well matured, well colored, and not ton firm to be yuite ripe, or : . least mellow, by the time it is placed on the market.

The peaches in these shipments that were hard and firm when shippesi reached the Winnipeg market without any perceptible change, while those 
that were matured enough to be semi-firm when shipped were in the best condition to attract buyers when placed on the market at Winnipeg.

One box of firstalass peaches, which at the peint of shipment had been recorded as "Nemi-firm and probably $1(x)$ ripe for shipment" was traced to the consumer and a special report was obtained on it. This box was packed on September 15th, londed September 16th, and sold at 11 in. nipeg on September 23rd. On September 26th the buyer reported that "al few of the pesiches were then mellow enough to luse, and by the end of the week the whole of the box weuld probibly be sulticiently ripe."

This may seem an exceptional case, and there is no doulit that the cool weather at Winnipeg after the arrival of the shipment aided in the keeping of the fruit. Still it establishes the fuct that if our finest peaches are allowed to altain full size and color befoic picking, and are then corsled down quickly and kept cool, they can be shipped or held st least two weeks and be in prime condition for use.

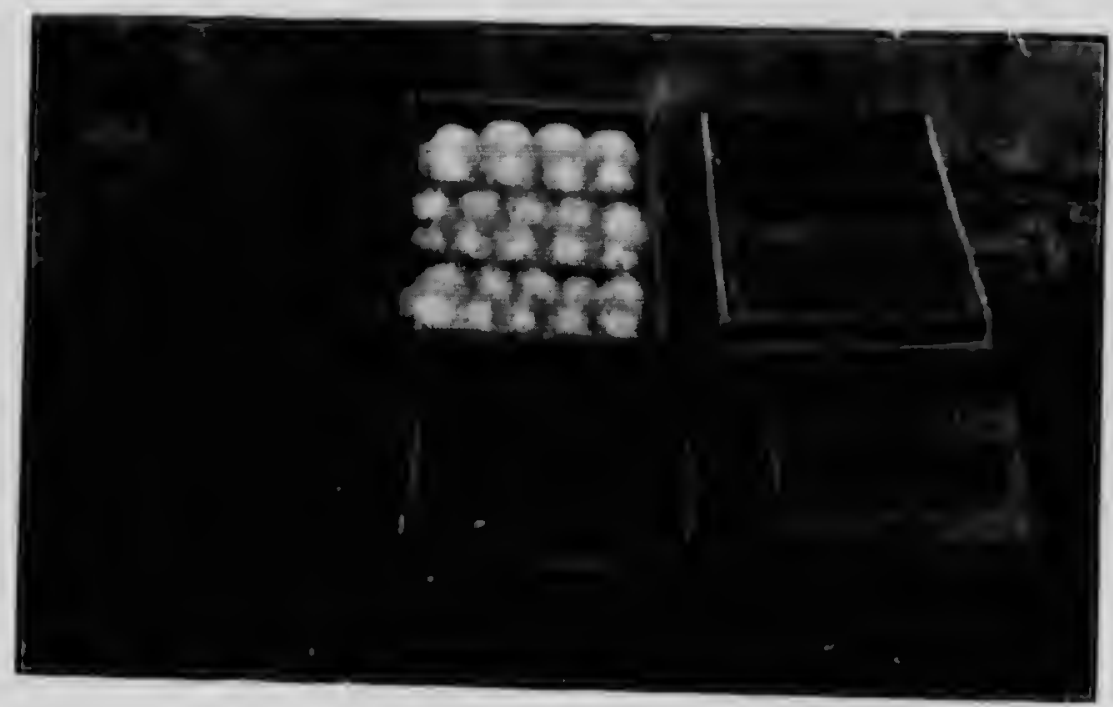

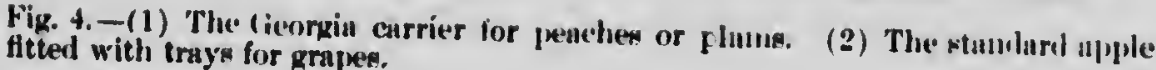

(2) Packacies. Owing to the fact that there are so many hinds of packinges in use for the different kinds of fruit, and that the fruit was supplied by a number of growers, there was no uniformity in the size and shape of the packages used in these shiprients. For several re:asons this was a decided disidvantage. They $\cdots$ \& not be picked to advantage in the car; when placed on the market they presented il motle! and unattractive appearance; buyers were at a loss to know which shape of package was really the best value for the money. Ill this could not but injure to some extent the sale of the fruit.

It was thought best, for these shipments, to adopt the box or crate package rather than the barrel or basket. .io barrels or baskets were sent except a few baskets of grapes from St. Catharines, which were placed 
on top after all the lxoxes had been loaded in the cur, in which position they carried all right. It is doubtful, however, if the basket is suflicieratly strong to stand the pressure when losded from the bottom to top of the car.

fior the apples, the box usced wis $10 \times 11 \times 20$ inches, the size adopted as the standard by the Ontario liruit (irowers' Awseciation. 'This Hakes " convenient shaped box for packing usid handling, and if it is to be the standard size, the sooner all shippers fall in line und inake use of $i t$, the better it will be for the trade.

For the pears three different shapes of boxes were used in cine cair; one

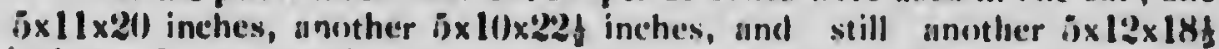
inches. It can readily be understoxd hr... awkward these various sizen were to pack tokether in a car. The first had been adopted as the standard pear box and is just half the size of the staudard apple lwox.

To secure uniformity in the pench packnges, boxes $6 \times 12 \times 18$, inches, the same size as the California pench case, were furnishet o those who had agreed to ship peaches. This may be a convenient size for picki. :s peaches and pears, but a more convenient size for shipping in mixed .. $r$ lots would be the standard pear box.

The grapes were shipped in the standarl apple box, fitted with twelve cardboard trays, havius: wooden ends, eisch tray holding about 2! pounds of fruit, as shown to the right in ligh. 4. This makes a very silfe and con-

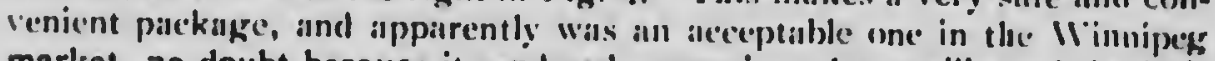
market, no doubt because it rendered convenient the retailing of the fruit in small quantities. This case, however, at the present price, 30 cents, is altogether ton expensive. A rase after the style of the (ieorgia peach carrier, as shown to the left in Fig. 4, is one well worthy of adoption by our growers. This case has been adopled almost entirely for the Georgia rench trade, and is lowked upon by the frait experts at the Jepartunent of Agricuiture at Washington as the best case in use for peaches, plums, and grapes This case complete, with the six 4-quart baskets, as shown. can be purchased F.C.B. Georgia at 12: cents. Suri ou. manuficturers could put up such il case for at least 15 cents.

Apart from the desirability of adopting is unifot style of package. there are two other respects in which the :reneral :ppearance of our packages might be improved. The lumber of which aliey are made should be neatly dressed, and the branding sh. Professor Reynolds, who accomparime' these car: to Winnipeg, had an opportunity of comparing our packnges with thcse in California shipments, which arrived while he was there. In this respect he says: "The geiseral appearance of our boxes leaves much to l:a desired. They are rough and unfinished. Dressing the nutside of the lumber of which they are made would cost only a trifle more, and would add much to their general appenrance, besides making any printing, stamping, or writing nore legible." With regard to the branding he says: "The desiguntions of the boxes. the packer's name, the variety and grade are not made'sufficiently distinct, and the styles of branding ore anything but uniform. The result is that it is often difficult to make out the names of the shippers or the variety or grade of the fruit: and wh' v viewed as a whole on the market, they presented a motley and unattractive appearance." 
(3) Gradic and Packisc. The car from St. Catharines was filled with apples, pears, peaches, plums, and grapes, the fruit being furnished by eighteten of the growers of that locality. Dominion Fruit Inspector Carey and I examined carefully a number of cases of each class of fruit put up by each shipper. A large number of the growers were present, and the one fault which was evident to all was the great lack of uniformity in grading, packing and branding. Evidently no two shippers seemed to have the same idea as to what constitured No. 1 or No. 2 grade of fruit. Some of the growers sent in first-class fruit packed in first-class style, but others sent in ungraded fruit, improperly packed and wrongly branded. From my personal acquaintance with many of the shippers concerned, I feel certain that none of them would intentionally do wrong in this matter; yet the fact remains that in a trial shipment made with the object of open-

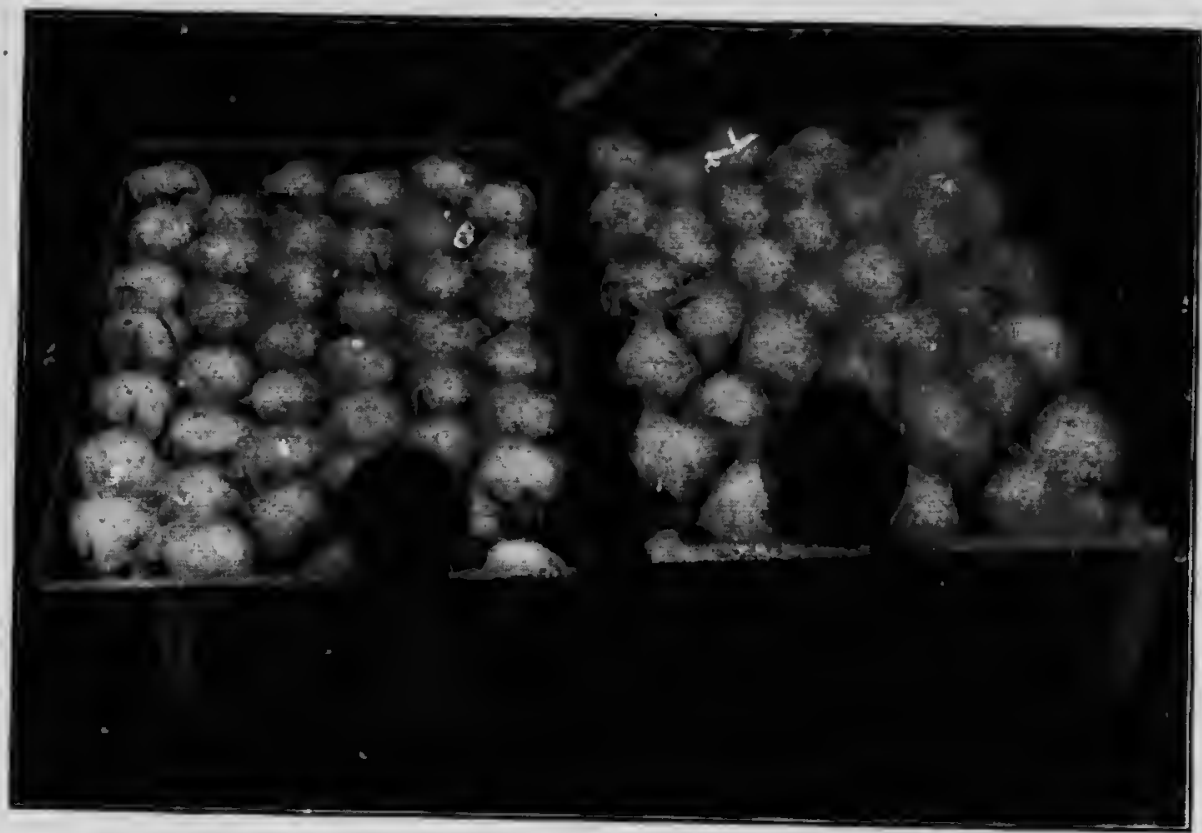

Fig. 5.-First-class peaches and pears, carefully graded and neatly packed.

ing up a new market, fruit was being sent which, because of the grading and packing, could not but bring discredit upon the shipper whose name appeared on every case, and could not but tend to close the market against even those who were doing all right, but happened to be in bad company. To avoid as much as possible such a result, we found it necessary in some cases to rebrand the fruit to a lower grade.

It so happened that there was present at the time of the shipment Mr. Carson, a Canadian, who was a few years ago engaged in fruit growing in the Georgian Bay district. He was an interested spectator, because he is now engaged in shipping California fruit to the Northwest market. He told us frankly that he had no fear of competition from Ontario so long as our fruit was sent in such condition, and, for the benefit 
of those present, a demonstration was given as to how the California fruit is graded and packed for shipment.

A few cases picked at randor: from Mr. W. H. Bunting's consignment were opened and exhibited as samples which might be depended upon to create a demand in whatever market they might be placed.

The majority of the shippers present were keen to learn and thankful for the suggestions given. One stated that the information gained from the object lesson afforded in grading and packing was well worth all the effort in getting up such a shipment.

From Grimsby the same kinds of fruit were sent, but the carload was made up by only six shippers; consequently, where there were fewer shippers each putting up from one to two hundred cases of his own, there was much more uniformity in packing; yet, even here, we found fruit packed in such a way that it could not but injure the reputation for Ontario fruit on whatever market it might be placed. It was plainly evident to those who examined the fruit that Ontario fruit-growers will have to bestir themselves if they ever expect to compete with California and British Columbia, which now have practically a monopoly on the Northwest market.

(4) Co-Operation Essential. The greatest need in this part of the business is more uniformity in grading and packing, and vigilant care that none but first-class fruit be offered for sale under a XXX brand. It appears to me that we will never satisfactorily meet these requirements so long as each grower is working alone and independent of his neighbor. What is necessary is, that in each fruit section the growers unite to form a strong co-operative association, that a good energetic man be selected as manager, and that experts be employed to grade and pack the fruit. This would probably necessitate the building of a central packing-house, and involve some expense, but the advantages to be gained would well repay for the outlay. Baskets, boxes and barrels could be purchased wholesale to better advantage; the grower could devote his whole attention to gathering the crop when in proper condition; the association would relieve him of all care and responsibility in grading, packing and marketing; and with this work in the hands of expert packers, the grade would be uniform, the packing carefully and properly done, and with a good business manager in close touch with the markets, the fruit could be marketed when and where it was most in demand. This in the end would result in increased demand on the part of the consumer and increased profits on the part of the producer. 


\section{TRANSPORTATION.}

(1) Londisg the Cak. In loading a refrigerator car with boxes of fruit, there are two conditions to be kept in view; a rigid structure, and provision for circulation of air on all sides of the boxes.

The plan in detail is illustrated in Fig. 6, which shows a number of boxes in position in the car. A row of boxes of the same length and depth was placed side by side, with ends butting against the end of the car, and separated from one another and from the sides of the car by narrow spaces. Across each end of the row a slat was laid, nailed to each box,

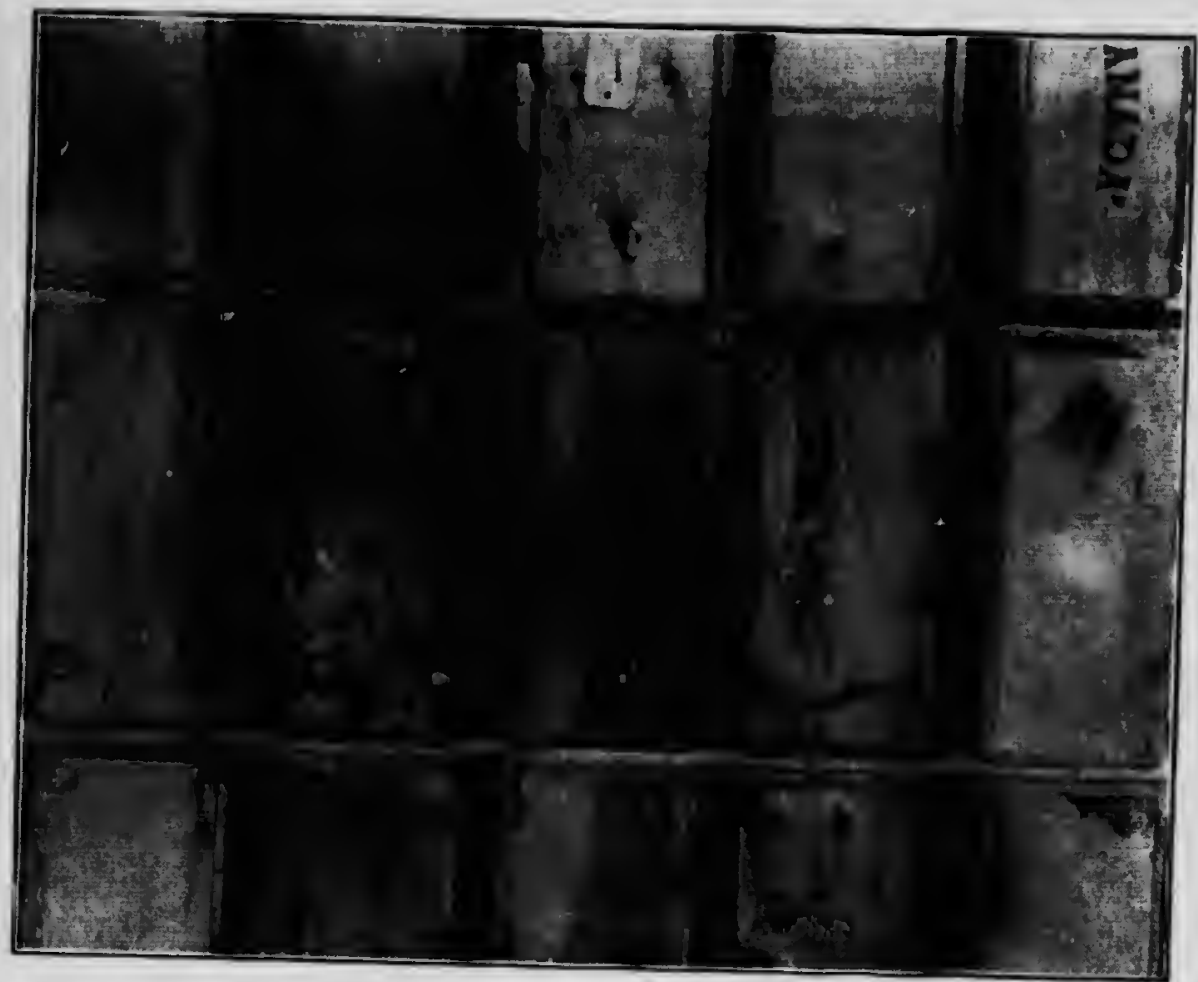

Fig. 6.

and butting against the sides of the car. This was repeated until a tier was formed as high as it was desired to go. Then another tier was built in exactly the same way, butting against the first tier, and so on from each end of the car, until it was filled. If any space remains over at the middle, too narrow for a tier of boxes, the load may be braced by
scantling.

(2) Rate of Despatcir. (i. T. R. The St. Catharines car left that point about 6 p.m. on September 14th, and arrived at North Bay about 7 p.m. on September 16th, having accomplished a distance of 300 miles in $4 y$ hours, at the average rate of six miles an hour. The second car left 
Grimsby at about the same time of the' day on September 16 th and reached North Bay at about 3 p.m. on September 18th, at about the same rate of despatch. Upon his return from the West, the writer communicated these facts to the Grand Trunk Division Freight Agent, and received the rollowing reply:

Dear Sra,-Your favor of the 8th inst. was received on my return to the city this morning.

I am sorry that there has apparently been some delay to your shipments of fruit from the Niagara District to the Northwest, in so far as our transportation service from shipping points to North Bay is concerned. I am taking matter up with our Car Service Agent with a view of seeing if a more satisfactory schedule can be arranged, and will advise you as soon as I receive his reply.

Yours truly,

\section{E. Dewey .}

C. P. R. The first car left North Bay at 2 p.m. on Saturday the 17 th, having been held over from the receding evening to take the fast freight. This through freight leaving North Bay daily at $z$ p.m. is due at Fort William at $4.30 \mathrm{a} \cdot \mathrm{m}$. on the second day following; the train to which the first car was attached was due at Fort William on Monday morning at 4.30. Having seen the first car out at North Bay on Saturday afternoon, and made all arrangements with the trainmaster and the yardmaster for proper attention to the second car upon its arrival, the writer proceeded on Saturday evening to Fort William, and reached there on the following evening. The next morning (Monday), the first car being due, inquiries elicited the fact that it had not arrived. Upon request, the chief despatcher traced the car, found that it had been laid over at White River for repairs, as the report said, and that it would arrive at Fort William that evening by the way freight. As to despatch from Fort Williain tc Winnipeg, the fast freight leaves Fort William daily at 5.30 a.m., and arrives at Winnipeg the next morning at 7.40. Thare is, however, a way freight that leaves Fort IVilliam in the evening, reaching Winnipeg some time the following night, and the yardmaster was requested to see that this car left by that train. The request was not attended to, and instead, the car was sent out by the through freight next morning, and reached -Winnipeg Wednesday m-ining about 9 o'clock. From the freight yards the car was next to be placed at the siding of the Ottawa Fruit and Produce Exchange on Princess Street. There is a Winnipeg by-law that forbids the shunting of cars on sidings between the hours $c .7$ a.m. and 12 p.m. Hence, by the failure to send the car out from Fort William by the evening train as requested, a delay occurred of 24 hours in the placing of the car.

Now, mark the case in brief. The schedule rate of despatch by fast freight from North Bay to IVinnipeg is 16 miles an hour. Provided the Grand Trunk would give the same service, the time from St. Catharines to North Bay would be 19 hours instead of 49 . Provided, further, that connection is made at North Bay with the west-bound through freight, and the time from St. Catharines, Grimsby, and other fruit sections ar- 
ranged accordingly, we should have, with the existing C. P. R. service, the following schedule, taking specific days and places for clearness:

St. Catharines to North Bay, 1 p.m. Friday to 10 a.m. Saturday; North Bay to Fort William, 2 p.m. Saturday to 4.30 a.m. Monday; Fort William to Winnipeg, $5.30 \mathrm{a.m}$. Monday to $7.40 \mathrm{a} \cdot \mathrm{m}$. Tuesday. To be unloaded and delivered on trucks, or placed on siding Wednesday morning. This would give a service of four or five days, instead of seven to eight days, as with the two experimental cars, and of ten longer as with ordinary shipments. Such a schedule is the above is perfectly feasible, and would require over the Grand Trunk portion of the line the establishment of a reasonably prompt through freight, and over the Canadian Pacific only the use of existing schedules.

The history of the second car was similar. It left North Bay on the afternoon of September 18, and according to schedule should have reached Winnipeg on the morning of the 21st. It reached its destination sometime on the 22nd, and was finally placed for unloading on the 23rd, seven days after loading.

These facts are reported not in any spirit of complaint, but simply to place upon record the conditions that surround freight traffic to the Northwest. It is quite obvious that over such an immense stretch of road, and with so large a volume of business as these' companies control, accidents and delays occur that are unavoidable. It is, however, within the limits of reasonable expectation that a five day service for tender fruits be arranged from Southern Ontario to Winnipeg.

A report of these facts was sent to the Assistant Freight Traffic Manager of the C. P. R. and it elicited the following reply:

Das SIn,-I am in receipt of your favor of the 8th, and am glad to learn the shipment of fruit to Winnipeg under your supervision proved a success.

In answer to your remarks regarding refrigeration, 1 would say it is expected and required that shippers will fully ice the cars at the point of shipment. If they instruct that the cars are to be re-iced in transit we will undertake to do this at each inspection and icing station, a list of which $I$ gave you, and where necessary the bunkers will be replenished with ice. You will understand, of course, that varying weather conditions have a marked effect upon the ice in the cars, and it is very desirable that even though the temperature may be cool at the time of shipment the shippers should see a full supply of ice is put in the cars, because a change might take place before the next icing station is reached, and unless the bunkers are full, the ice may have disappeared before we have had an opportunity of inspecting or re-icing.

With regard to the time in transit. So far as our line is concerned from North Bay to Winnipeg, there is no reason, barring accident, why we cannot keep our schedulo in the handling of fruit cars. You will understand, however, in a haul of such a length interruption may occur from time to time from causes over which we have no control. Fruit and other perishable freight is invariably handled on our line under red cards, and is followed by telegraph through each divisional point by our Superintendent of Car Service to insure despatch. We cuuld not undertake to guarantee the time in transit. We will undertake, however, so far as we can, to see that fruit is given the best sossible despatch at the time of handling. Your suggestion that we might run a special service once a week or oftener has already been found to be impracticable. We endeavored to establish such a service on a previous occasion, but found we could not induce the shippers to guarantee a sufficient number of cars to enable us to carry it out. In fact the dealers seemed to be disinclined to 
sh'p at the same time, and I believe there is also objection to their goods reach. ing the market at the same time, ca using an overstock and sometimes a falling
in prices.

I may say I am forwarding your letter to our Freight Traffic Managor, and will ask him to comınunicate the contents to the Superintendent of Car Service and our Superintendent of Transportation. I am sure both these gentlemen will do everything in their power to assist in the shipment of fruit from Ontario
points to the west.

Yours truly,

W. B. Bunlixa.

(3) Icisc. This particular, though deserving separate mention, will be briefly dealt with. The second car, from Grimsby, arrived at North Bay, according to the report received, with bunkers only one-fourth full of ice, and three tons of ice were: added at that point. The amount added to the first car at North Bay was about one ton and three-quarters. The1 being no icing station at lirimsby, when the second car lelt there special instructions were given tor re-icing at Hamilton. This probably was not done, and the car having been iced at Haniiton before loading on Wednesday, was not re-iced until it reached North Bay on Sunday. Excepting this omission, the icing was well attended to all along the line. The first car on reaching North Bay was about two-thirds full, and was filled there. When it reached Fort William it was full of ice, having probably. been iced at Shhreiber. No data were obtained with respect to the total amount of lce consumed, nor would such data be of much value by reason of the infinite variety of weather conditions that surround different shipments.

Under this head the attention of the reader is direted to the remarks on icing in the letter quoted just ahove.

(4) Charges. News was received at St. Catharines, before the first car was sent out, respecting the reduction of freight rates from 84 cents to 66 cents per hundred for mixed fruic. It is likely that our cars were the first to benefit by the more favorable rates. The change made a difference of $\$ 36$ on each carload, 9 cents on a bushel of apples, and nearly 4 cents on a box of peaches.

The new rates for icing not having been fixed when the transportation charges were sent in, a tlat rate of $\$ 16$ was charged, which brought the total charge up to 74 cents a hund ed for a carload of 20,000 pounds.

Before plans for the experiment were completed, the authorities of the Dominion Express Company were interviewed with a view to shipping an express load on one of the Company's patent ventilated cars. A request was made for a quotation of rates on carload lots from St. Catharines to Winnipeg. The Doninion Express Company not having rail connection at St. Catharines, the quotation was to include the Canadian Express charge from Si. Catharines to the point where the Dominion Express would take charge of the car. After consideration, the conipany offered to carry the car, upon payment of the local rate of the Canadian Express Company, 30 cents a hundred, and a further charge of $\$ 2.25$ a hundred for the portion of the line over which the Dominion Express ran, making a total of $\$ 2.55$ a hundred. To this an alternative ivas offered by the company, namely to ship the fruit by electric line to Port Dalhousie, tranship to boat for car- 
riage to Toronto and tranship again to the company's car at Toronto. This involved handling four times instead of twice, and loiding twice by the company's agents. Success in shipping to the West requires as little handling as possible and careful loading, hence the alternative as well as the original offer, was dismissed as impracticable.

A comparison of express rates per ordinary car, namely $\$ 2.10$ a hundred, with freight rates, 74 cents, gives the following figures, for tender fruits :

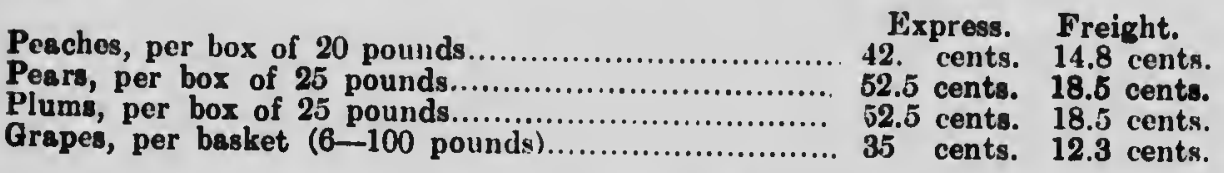

An express car loaded at Grimsby could be placed and sold at Winnipeg three days after. But tender fruits well-selected, well-packed, and well-loaded would be safer in a refrigerator car for six days or eight days than in a hot, unventilated express car for three days. Our experimen: has proved that tender fruits can be carried by freight with safety; and as to rates, the total freight charges are a little more than one-third of th: express rates.

\section{OBSERVATIONS ON THE MARKET IN WINNIPEG.}

(1) Tile Prices Obtained, and Condition of Fruit. The following tables present in concise form information respecting the grade, quality and rondition of the fruit, and the prices obtained. The column under "Net Proceeds" gives the returns to the grower after deducting cirarges for freight, commission, and cost of package, but not ior palking and wrapping.

Peaches: The package used contains, in peaches wrapped in manilat paper and tightly packed, slightly more than the 11-quart basket of bare peaches, about 13 quarts. Crawford peaches, XXX, realized from 85 to 90 cents net; Crawford XX, 70 to 80 ; Elbertas, $62 \frac{1}{2}$ to 80 .

These prices compare very favorably with those obtained locally in Ontario this year, and Ontario prices this year are unusually high, while at Winnipeg.pricer are no higher than usual.

The peaches sold entirrly on their appearance and quality, with no reputation to help them. It is : ery gratifying to note that the prices were fully equal to those for the best California peaches on the same dates. The greater size of the California fruit was quite counterbalanced by the superior brightness and color of our fruit.

With respect to competition of Ontaric peaches with the Western product, it shou!d be borne in mind that the latte: suffers a serious handicap in the matter of charges. Against a freight charge of 15 cents on a box of peaches from Southern Ontario to Winnipeg, there is a freight charge of 36 cents from California, and in addition a duty of 19 cents, making a total of 55 cents - a handicap of 40 cents a box. In a letter addressed to a Winnipeg commission firm, the writer saw quoted 50 cents 
a box F.O.B. California. To compete with these California prices, peaches might bo quoted 90 cents a box F.O.B. St. Catharines or Grimsby. In fact, with one exception, prime Crawford peaches sold in advance of this price, and the average net price obtained for No. 1 Crawfords, counting the price of the box, was 92 cents.

$$
\begin{aligned}
& \text { Package, }-43 / 4 \text { in. } \times 12 \text { in. } \times 1 \times 1 / \text { in ; cost, 8c. } \\
& \text { St. Catrukines. }
\end{aligned}
$$

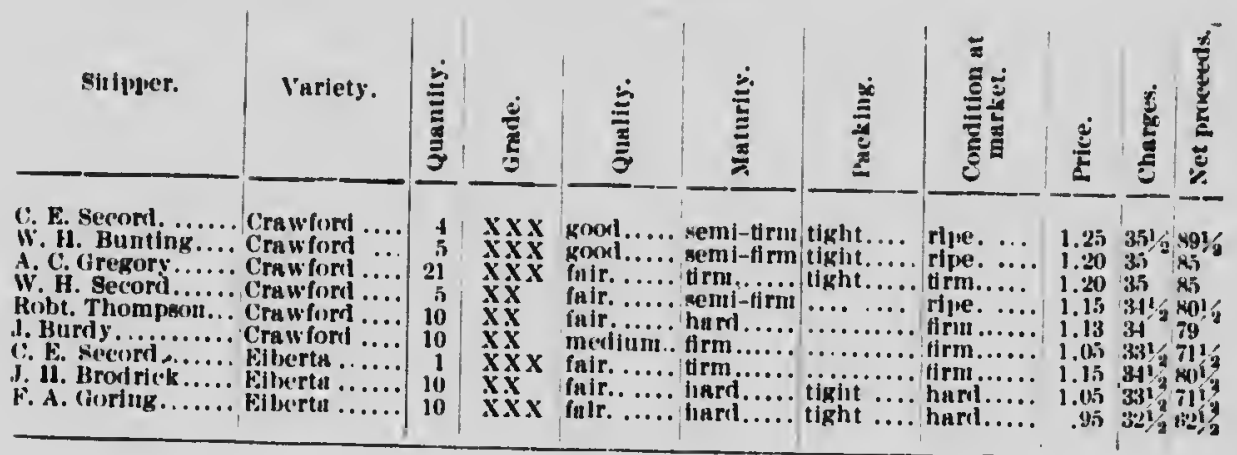

Grinsby.

W. J. Droje. ...... Crawfurd .... 3

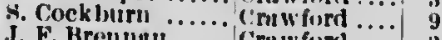

J. F. Brentau..... Craw ford …

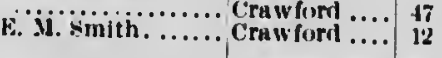

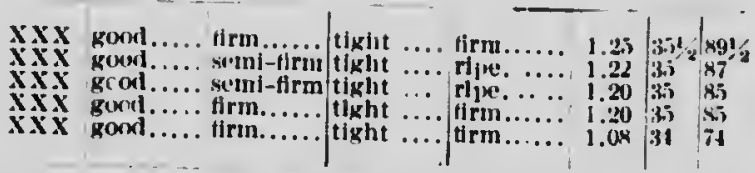

The low price on the last lot- -7 tc. net-- was due, not to any inferiority in the fruit, but simply to the uncertainty in the nethod of sale.

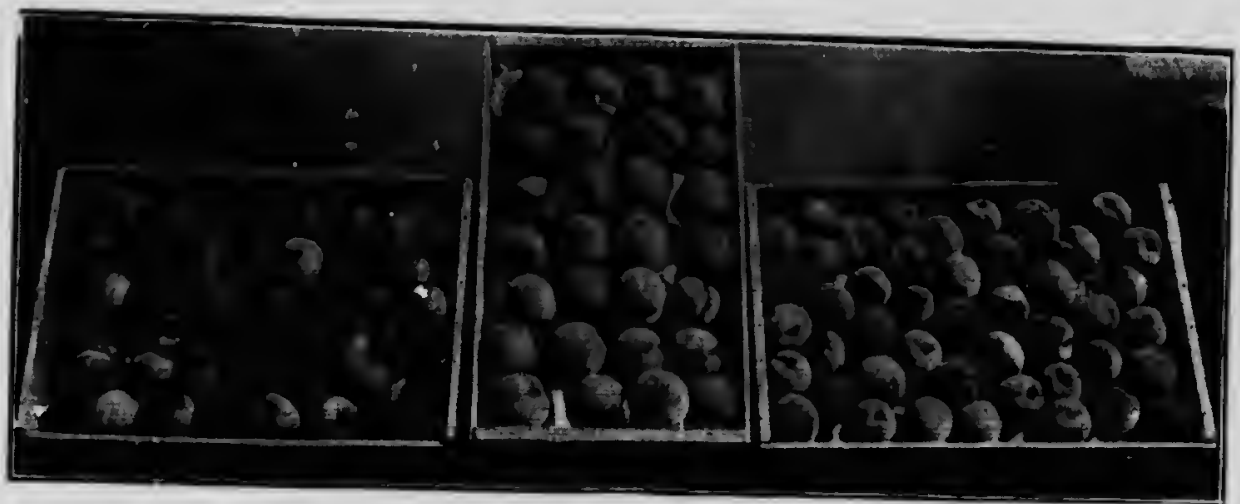

Fig. 7 shows two boxes of Ontario peaches with a box of California peaches between. It may be seen that the California fruit is larger; but in other par. ticulars the Ontario fruit is superior. The photograph does not do justice to the fine colors of the Ontario fruit. A close inspection, however, will reveal these colors. The California box of fruit is uniformly pale, while the Ontario specimens show dark and pale alternately. The dark is, of course, the colored side of the peach, and the fine appearance of the original, as contrasted with the paleness of the California product, is at unce evident. 
Plums: The dealers at Winnipeg seemed somewhat timid in purchasing the plums, and did not offer high prices, although the fruit was in good condition. In terms of the 11-quart basket, the Reine Claude plums netted 47 cents, the Yellow Egg 54 cents, and the Grand Duke and Glass 48 cents. Th.ese prices are of course much below Ontario prices this year, and would not be considered high at any time.

Package, -12 -tray crate, 10 in. $\times 11$ in. $\times 21$ in. : 27 pounds of fruit. St. Catharines.

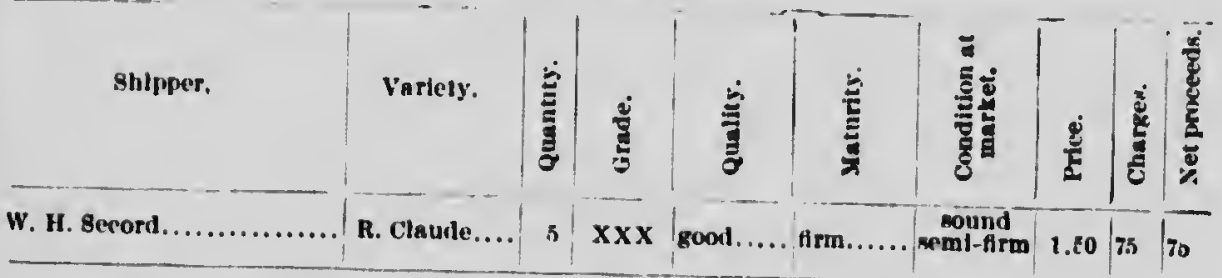

Package,-2-basket crate ; 20 pounds of fruit.

Grimsby.

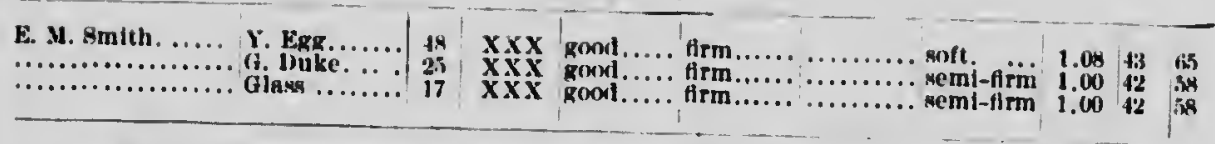

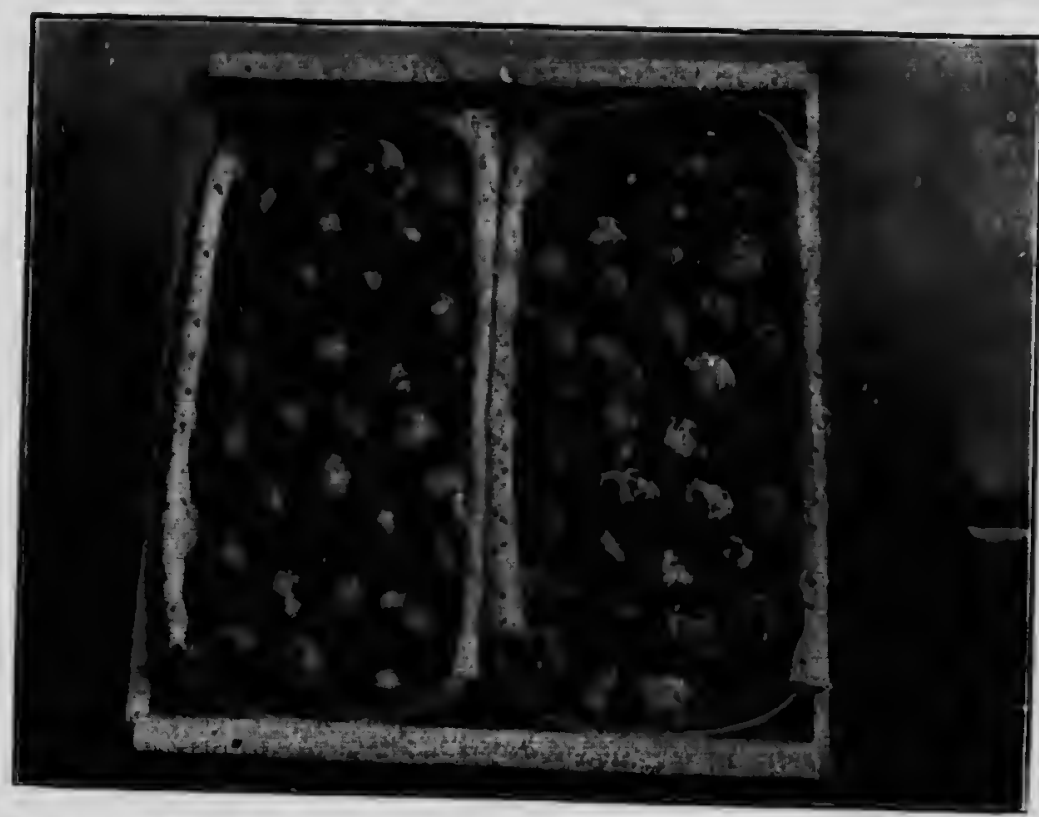

Fig. 8 shows the 2-basket-crate, and the condition of the plums at Winnipeg. The basket at the left contains Yellow Egg, the other Grand Duke. The spotted These plunis are shorn juster is do the partial bloom remaining on the fruit. quite sound. 
Grapes: With the exception of one lot of Moore's Early, of which a large percentage were off the stem, and which netted $66 \mathrm{cents}$, and one. crate of Concord, which netted 70 cents, the grapes realized prices ranging from 75 cents to $\$ 1.02$ per crate of 30 pounds. After deducting all charges and cost of packing, 40 to 50 cents a basket would be very nearly the equivalent of these prices. Had it not been for the excessive cost of the crate used-30 cents - the results would have been even more satis. factory.

Package, -Crate, 10 in. $\times 11$ in. $\times 21$ in., 12 trays ; cost, 30c. St. Catharines.

\begin{tabular}{|c|c|c|c|c|c|c|c|c|}
\hline shlpper. & Veriely. & 总 & है & $\stackrel{3}{3}$ & 袅 & 룰 & E & 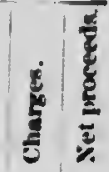 \\
\hline 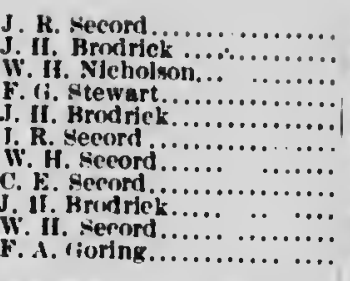 & 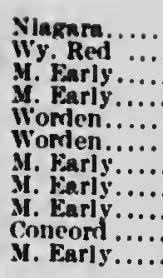 & $\begin{array}{r}2 \\
3 \\
3 \\
20 \\
4 \\
4 \\
2 \\
2 \\
10 \\
8 \\
1 \\
10\end{array}$ & 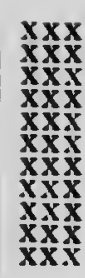 & 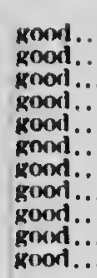 & $\begin{array}{l}\text { ripe... } \\
\text { trmi... } \\
\text { ripe... } \\
\text { rlpe... }\end{array}$ & $\begin{array}{l}\text { mound.... } \\
\text { mound.... } \\
\ldots \ldots \ldots . . . . . \\
\text { soivid..... } \\
\text { mound.... } \\
\text { mound... } \\
\text { off stem... } \\
\text { sound .... } \\
\text { sound.... } \\
\text { off ntein.. }\end{array}$ & $\begin{array}{l}1 . .00 \\
1.75 \\
1.65 \\
1.65 \\
1.60 \\
1.60 \\
1.610 \\
1.52 \\
1.00 \\
1.45 \\
1.40\end{array}$ & 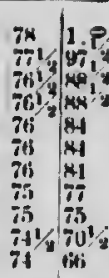 \\
\hline
\end{tabular}

Perurs: Packages, - 5 in $\times 10$ in. $\times 221 / 2$ in.; 5 in. $\times 11$ in. $\times 20$ in. ; 5 in. $x 12$ in. $x 181 / 2$ in ; cost, $x .10$ c.

GRIMSBY.

\begin{tabular}{|c|c|c|c|c|c|c|c|c|c|c|}
\hline shipler. & Variety. & 竎 & 䒿 & 吾 & & 苨 & 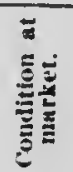 & نِ & $\frac{6}{\underline{\Delta}}$ & 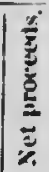 \\
\hline
\end{tabular}

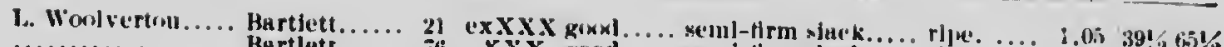
$\ldots \ldots \ldots \ldots \ldots \ldots \ldots$ bartlett.......

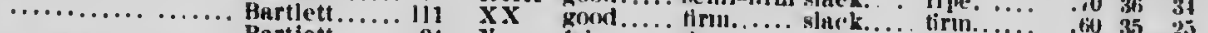

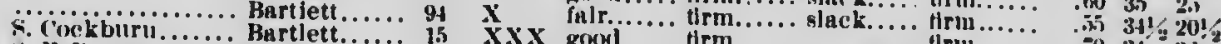

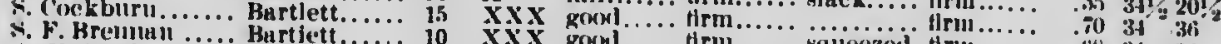

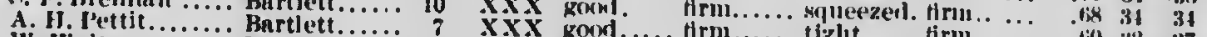

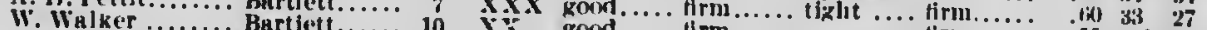

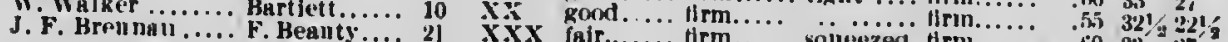

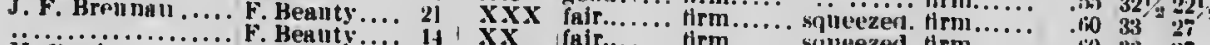

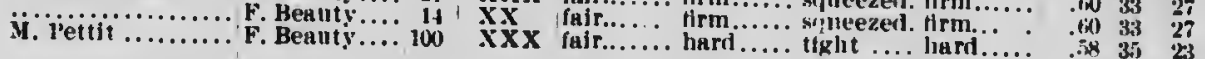
Package, -5 in. $\times 10$ in. $\times 2221 / 2$ in.; cost, 10 c. St. Catharines.

H. S. Cole ... .... Bartlett...... F. Biaikle ........ Bartlett........ 2t J. H. Brodrick ..... Burtlett....... il J. Burdy .......... Partlett ...... II Tltterington \& $\mathrm{Co}$. Bartlett...... R. F. Robinsul.... Bartlett...... 20 Robt. Thom psou... Bartjett......

A. C. (iregory....... Bartlett....... 20

J. H. Brodrli.k..... Seckel ......

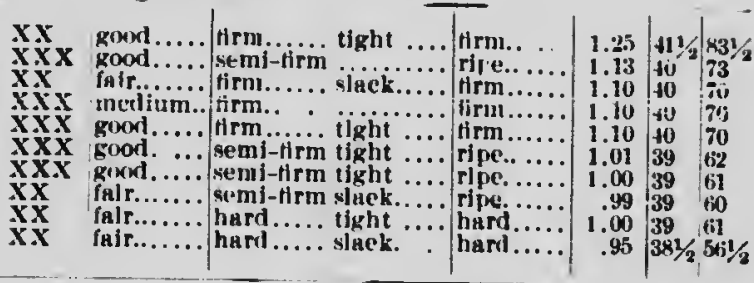


For the sake of comparison, four lots of pears from one orchard, graded Extra XXX, XXX, XX, and X, are placed together. The Fletmish Beauty lots, while good stock, were altogether too immature, and, as the prices show, were not wanted.

The pears shipped by $H$. S. Cole were marked $\mathbf{X X}$ on account of being ungraded and having a few small ones in each box. They were all of good quality and for the most part large enough for XXX.

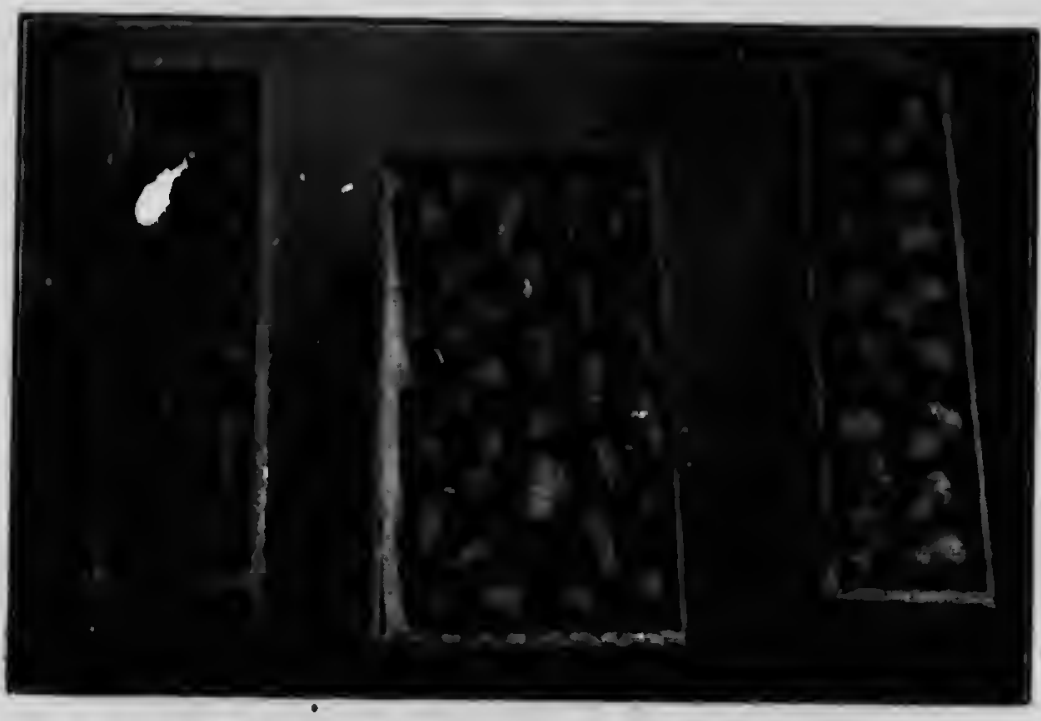

Fig. 9 shows XXX Bartlett pears at Winnipeg. For the photograph, the wrapping was remored and the pears rearranged.

Apples: Package, -10 in. $\times 103 / 4$ in. $\times 21$ in.; cost, $14 \mathrm{c}$. St. Catharines.

Shlpier. $\quad$ isiets.

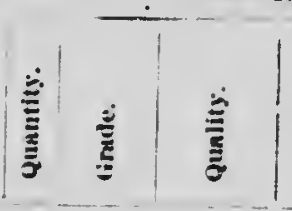

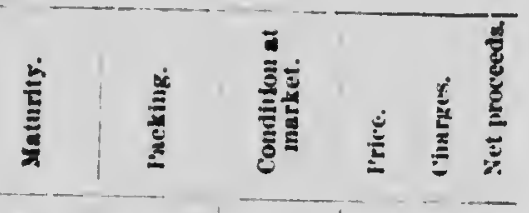

\$V. U. Bunting .... st. Lawrence 13 Titterington di co.. Gravenstein. 21 J. R. Serort ........ B. Hppin.... .

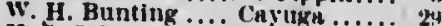
H. \$. Coie ......... Chyuga ...... 10 C. E. Secorr ...... Graventeint . 2t ............... II. Piplin.... 13 Robt. Thonipsun ... (iravenstein ....... W. H. Bunting .... St. Lawrence 11 A C. Gregory ... oivert ...... 13 J. H. Brodrick: "aithy....

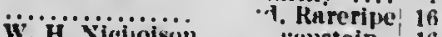
C. F.. Fecoth ...... firt Yetistcin . 16 A. C. Gregory ...... K. Mppin.... t J. H. Brodrik .... Kes. Codiing. .................... Crab. . t bu

The Cayugas shipped by H. S. Cole were ungraded and, therefore, markell $b \cdot$ the inspectore $\mathbf{X} \mathbf{X}$, although mostly $\mathbf{X X}$ stock. 
Puckuge, -10 in. $\times 10 \frac{1}{4} \mathrm{in} . \times 21$ in.; cost, $1+\mathrm{c}$.

(jRIMsny.

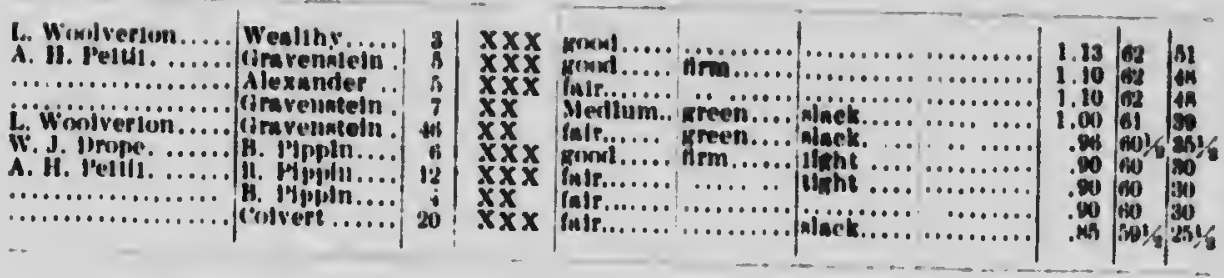

Tomoutos: : Package, $-43 / 4: \times 12 \mathrm{in} . \times 1 \% 1 / 2$ ir.. ; cost, $8 \mathrm{c}$

St. Cathakines.

\begin{tabular}{|c|c|c|c|c|c|c|c|}
\hline Wh/pjuer. & $\stackrel{3}{\Xi}$ & $\sum_{5}^{\circ}$ & $\frac{3}{2}$ & $\begin{array}{l}5 \\
5 \\
\frac{3}{3} \\
\frac{3}{3}\end{array}$ & $\underline{E}$ & है & 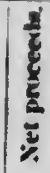 \\
\hline 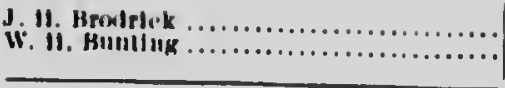 & 17 & $\underset{\mathbf{X}}{\mathbf{x}}$ & $\begin{array}{l}\text { ruither wreen.. } \\
\text { dto }\end{array}$ & • & . & lan & 1012 \\
\hline
\end{tabular}

Grimsay.

W. J. Indrew....................., 30 $\mathrm{x} \times \mathrm{x}$ ruther

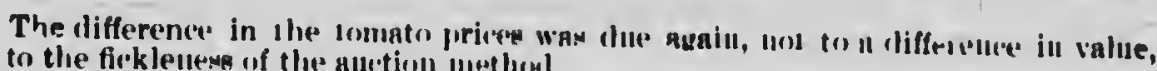
but to the firklellewe of the aurtion unethin].

Comparing Winnipeg prices with those obtained in local and other marl.ats this year, Mr. W. H. Secord, of Homer, Ont., Writes: "I received as high as $\$ 1.25$ per 11 -quart hasket for Reine Claude plums in Montreal, and it took eight biskets to fill five hoxes. As to pealches, I shipped the same peaches to Toronto the next dily after I delivered to you and received 80 cents per basket, which would net $6 ; 13 \frac{1}{2}$ cents deducting freight, commission, and bisket. On the whole, in my npinion, the prices realized do not equal those which we are receiving in the East this year. I am not prepared to say how it would be in a year like last, of plenty."

Mr. J. W. Brennan, of Grimsby, writer: "Our returns on peaches shipped the following day to Ottawa and Quebec netted us clear $\$ 1.25$ and $\$ 1.29$ per case.

"Just received returns from Glasgow, where a car of pears arrived in bad order, much too ripe. In that consignment our little lot brought us i0 cents clear; on others we believe iess than one-half were realized."

(2) Method of SAl.E. The fruit was sold by auction, and the method exhibited its usual advantages and disadvantinges. It is inclined to unsteadiness. A glance over the tables of returns given above will reveal differences in prices that are not due to differences in values. On the other hand, this method enables rapid disposal of the goods, which is of importance for perishable fruits, and quick returns, which is satisfactory to 
the shipper. With ' un limited experience, however, the writer does not feel competent to advise upon the method of selling, whether this or any
other.

(3) Cuaractik of Fulit Drmanded. If one may judge from the sale of two cars of mixed fruit, the market there demands well-matured, bright fruit of clean, sound appearance. IVell-colored Crawford peaches sold much in advance of Elbertas, which, though large, were mostly hard and green. Immature fruit is not wanted. Many of the pears in the second day's sale were green and very firm, and sold low accordingly. Of apples, well-colored Gravensteins, Wealthy, Alexander, and St. Lawrence, commanded the best prices.

(4) Best Degrfi of Maturitr. A careful examination of the fruit at Winnipeg revealed the fact that the most nature fruit at shipping point was in best condition at the market. Evidently ull classes of fruit may be left on the tree until full size and characteristic color have been attained, but should bi picked frm, and before the yellow tints, significant of ripeness, have begun to appear. Peaches and pears that were shipped hard and green reached the market without any perceptible change; those that were semi-firm at shipment had become sufficiently mellow to be in good usahle condition. A special report was obtained of one box of peaches, among the primest of our two lots. This box at shipping point was reported "semi-firm, a little ton ripe for shipment," and the peaches were large and well-colored. It was packed on September 15th, loaded September 16th, and sold at Winnipeg September 23rd. On Monday. September 26th, a report was obtained to the effect that only a few of the peaches were then mellow enough to use, and that by the end of the week the whole of the box would probably be sufficiently ripe.

It seems an opnortume moment to emphasize the importance of choosing carefully the time for picking anci, for fancy fruits at least, of going over the tree several times and picking only the ripest at each picking. This phase of the question stands out clearly as a result of our experiment. The fruit should be allowed to attain on the tree its distinctive character, in sizel color, and flavor. If, in these three particulars, the fruit is imma. ture when picked, it will remain immature. And further, if fruit suf ciently mature to have its distinctive size, color, and flavor when picked, cannot be safely carried to market, then it is detrimental to the reputation of the fruit to carry any. The shipping of immature fruit, it is admitted, has don as much as anything to depreciate prices in distant markets.

What does the grower gain by the careful selection of fruit on the tree and by successive pickings? He gains (1) a greater quantity of fruit, since the smaller specimens are allowed to grow; $(2)$ fruit of better appearance, on account of greater size, more uniform size, and higher color; (3) fruit of better quality; (4) in a discriminating market, better prices; (S) a better reputation.

(5) PAckine as it APPEAREd It TII: MNkKFt. By packing is meant not merely the placing of the fruit in the package, but also the use of wrappers and fillers.

Two effects should be borne in mind in the packing of fruit: First, the condition of the fruit; second, the appearance of the package. 
Packing should first of all be tight; and herein much , the work done for the two trial shipments was defective. Many of the w)xes, upon being lifted to load in the ar, rattled, which indicated a looseness of tise fruit in the package. It acarcely necessury to remark that such looseness is an unfavorable factur in the carrying of the fruit, and that it is useless to secure the package in its place in the car when the fruit within the package is capable of being displaced. Further, the looseness of the fruit. when the package is opened for exhibition and sale, impresses the denler unfavorably, and tends to depreciate the price. Tightness of packing is just as necessary when the fruit is wrapped, as when it is not; for with loose packing and heavy wrappers, such as occurred t(x) frequently in this shipment, the purchaser receives much less fruit than, if he judges by the size of the package, he expects and is entilled to receive. To illustrate: the weight of a box of peirs put up by one shipper was 31 pounds; the

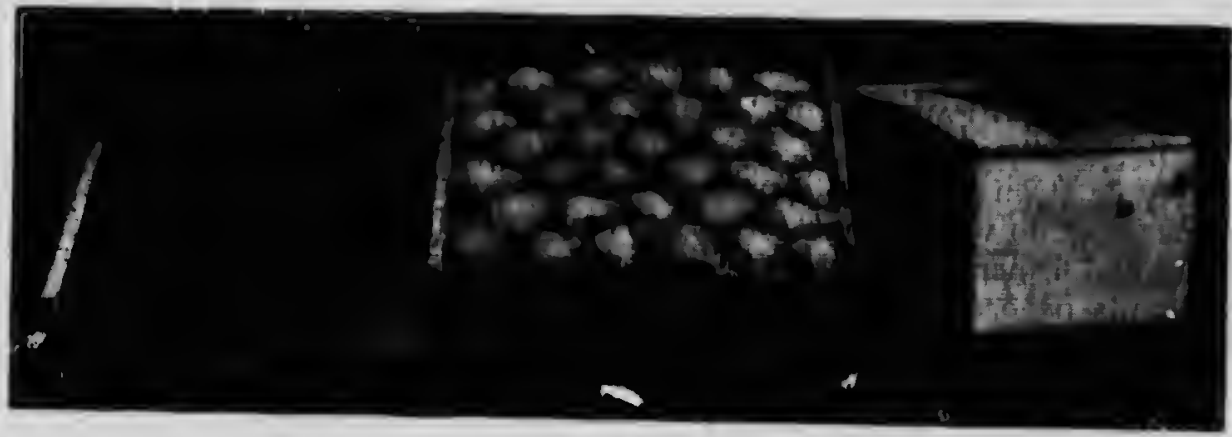
1

Fig. 10.-(1) The Calitornia graper s muare traye.

(2) A box of pears packed ly J. F H heaped toward tho middle by selectiug slightly Brenun, of lirimuby. The pear are heaping gives the effect. when the lid is on, as seen in (3) of this the middle; this

(9) Is 4 box of California peans 9 in, as seen in (3) of this figure. packing the pears are squeezed when the lid is in. $x$ is . in. By this atyle of apples when beading the barrel. weight of a box of same size, containing the same variety and grade of pears, put up by another shipper in the same car, was 23 pounds. The pears in both boxes were wrapped, but in the one the pears were squeezed,
and in the other they were slack.

Some of the apples in our shipistent were packed in layers, with a stiff heavy paper, cut the size of the box, between layers. This paper, while good in itself, was made by some of the packers the occasion for very loosc packing. In fact, in some of the boxes there was no attempt aced stem upwards so as to present a level surface for the next paper.
Such methods resuit to the packer in a con rob the consumer, the packer in a considerable saving of apples, but

Fiulers.

condemned, namely, is a practice in packing that cannot be too strongly sior, and small and infe-ior in the slack with odd pieces of paper, excel- 
the intending purchaser, when the box is opened, has to be seen but once to impress anyone with the unwisdom, the shortsightedness of this style of work. The ragged, untidy, make-shift appearance, the evident lack of skill, the danger that dishonest intention be imputed, are some of the unfortunate consequences. The filling known as "Excelsior" is in this regard made to cover a multitude of sins, and for this reason, if for no other, its use should be discouraged. Especially is excelsior superfluous when the fruit is wrapped, as then it is not required to serve its only useful purpose, namely, to prevent the fruit from bruising. Yet by several of our packers excelsior was used to fill up the slack between the top layer of peaches and pears and the lid; whereas, with a proper selection of size of specimens and ordinary care and skill in packing, there should have been no slack. With excelsior at the bottom of the box, and excelsior at the top, and excelsior sticking out at the crevices and forming a ragged edge all around, the appearance of some of our peach boxes compared very unfavorably with the neat and tidy Californian boxes in the same warehouse, ard, it is only just to say, with other boxes sent out by our own packers.

Wrapping PAPER. The writer is inclined to advise, but without having personally made an exact and thorough test, that tissue paper is not heavy or strong enough to protect Ontario peaches in shipment. Tissue paper may do well enough for pears, or for California peaches, which are drier and firmer than our own; but for the soft and juicy peach of Ontario a manila paper seems to give better results. This, however, should not be so thick and heavy ar to bulk up unnecessarily, and particularly, stiould be of a si-" proportioned to the size of the fruit to be wrapped. Here again, the :-suffering consumer, who thought he was paying for prime Ontario peaches, found upon opening some of the boxes that he had purchased large twists of paper, with a comparatively insignificant peach done up in a pocket at the end of each. In many cases, the paper used was altogether too large. Now, what does this fact signify? Evidently, that tise packers were not in the habit of wrapping their peaches for market, were not provided with paper of the proper size and weight, and when the time came for them to fulfill this contract, were forced to use whatever was at hand, or could be procured at short notice. One packer, driven to desperate expedients, but as he confessed, well aware of the ludicrous nature of the performance, used toilet paper for wrapping his pears. It is quite evident that the business of packing the fruit has not yet received serious attention from many of our fruit-growers. The time is coming. and cannot come too snon, when peaches will be wrapped and boxed for
shipment to our local markets. 


\section{SOME NOTES ON DIMENSIONS OF PACKAGES IN RELATION TO COOLING.}

The question of size and shape of package to be used with any particular variety is of first-class importance in storing or shipping fruit; important not merely in respect of cost and convenience of package, or the degree of firmness of the fruit that will sustain the weight of the fruit above it in the package; but important more especially on account of the rate at which the whole of the fruit in the package will cool to the temperature of the refrigerator. Slowly ripening fruits, such as winter apples and winter pears, may be safely packed in a case that cools slowly. But quickly ripening fruits, to be preserved, must be cooled very quickly to a temperature of 40 degrees or below, in order to delay the ripening and decaying processes. With a peach that will ripen and begin to decay two days after picking, a few hours' delay in cooling will make relatively a great difference in the length of its life. For such fruit as this, a package must be used that allows the most rapid rate of cooling.

With these principles in mind, the following temperature tests were made at the Cold Storage Warehouse at the Agricultural College. Four packages were filled with apples, and long thermometers were inserted in the midst of the fruit, the bulbs being at the centres of the packages and the stems and reading scales standing out of the packages in view of the observer. The packages were then headed, placed in a warm room and kept for a week until they reached a uniform temperature of 64 degrees $F_{.,}$and then were transferred to a room in the warehouse that is kept at a temperature of from 32 degrees to 34 degrees. The packages
were:

1. An ordinary large apple barrel. tight.

2. A bushel box $10 \times 11 \times 20$ inches, with close joints practically air

3. A Georgia peach carrier $10 \times 11 \times 20$ inches, with open spaces at sides; the fruit within was packed in the six baskets, and among these baskets were empty spaces permitting circulation of air.

4. A half-bushel box $5 \times 11 \times 20$ inches, with open spaces at sides, bottom and top.

(1)

\section{Package}

Barrel

Bushel (cioged joint. . . . . . .

Bushel (open) $\ldots \ldots \ldots \ldots \ldots \ldots \ldots$

Half-bushel ................ (2)

Barrel ...................

Bushel (closed joints)............

Bushel (open joints) $\ldots \ldots \ldots \ldots$

Half-bushel ............... Total :

Barrel

Bushel

Bushel (open joints) $\ldots \ldots \ldots$....

Half-bushel
Time of observation

a.m. p.n.

10.30 to 2.00

10.30 to 2.00

10.30 to 2.00

10.30 to 2.00

p.m. p.m.

2.00 to 8.00

2.00 to 8.00

2.00 to 8.00

2.00 to 8.00

a.m. p.1I.

10.30 to 8.00

10.30 to 8.00

10.30 to 8.00

10.30 to 8.00

\section{3. hours \\ $3 \frac{1}{2}$ hours \\ 31 hours \\ $3 \frac{1}{2}$ hours}

6 hours

6 hours

6 hourg

6 hours

$9 \frac{1}{2}$ hours

9. hours

9. hours

91 hours
Amonnt of cooling

$\begin{array}{llll}64.5 & 60.5 & \text { equal } & 4 \\ 64.5 & 57.5 & \text {. } & 7 \\ 64.5 & 54 & \text { ". } & 101^{\circ} \\ 64 & 51 & \text { " } & 12^{\circ}\end{array}$

$90.5 \quad 57$

57.550

$54 \quad 43$

$51 \quad 40$

$\begin{array}{ll}\text { " } & 314 \\ \text { " } & 71 \% \\ \text { " } & 110\end{array}$

$94.5 \quad 57$

$64.5 \quad 50$

$64.5 \quad 43$

64 40 
The half-bushel, it may be seen, had cooled to a sufficiently low temperature, 40 degrees, in $9 t$ hours; the Georgia crate, with open sides and open packing, cooled in the same time within 30 degrees of that temperature. By the next morning at eight o'clock the half-bushel had cooled to 35 degrees, the Georgia crate to 35 degrees, the bushel to 39 degrees, and the barrel to 47 degrees. Two days after the commencement of the observations the barrel was still at a temperature of 38 degrees, 6 degrees. above that of the room.

Thr splication of these facts is obvious : Winter apples and winter pears $n_{1}$, , so far as temperature and ripening are concerned, be packed in barrels. For winter pears, no package smaller than the bushel box need be used. Between the half-bushel and the bushel, there was in the above test a difference of 12 hours in cooling from a temperature of 64 degrees to $\mathbf{4 0}$ degrees; but this difference is insignificant with slowly ripening fruit.

For summer and early fall apples the barrel is too large a package, and much of this fruit shipped in barrels turns out badly by reason of the slowness of cooling. Where decay occurs it is usually at the centre of the package, because this is the last to cool. The bushel box, cooling to the centre in half the time that !he barrel equuires. is for this reason preferable to the barrel for early apples.

For early and quickly ripening pears. the bushel box is too large a package for best results in !crg shipments, unless it be in the form of the Georgia carrier with open sides, when it resolves itself virtually into a number of small packages with spaces between. The writer chanced to call upon a retail dealer at Winnipeg and found him unpacking some Ontario pears, Bartletts, from bushel boxes. There was a marked difference between the pears next to the package and those at the centre. Those at the outside were still green and frm, while those at the centre were quite ripe, and many of them soft and pulpy. The use of the halfbushel box in this instance instead of the bushel, would have hastened the cooling of the centre of the package by 12 hours, and would likely have preserved the fruit at the centre.

All results of storage and shipping experiments concur in pointing out the necessity for quick cooling of tender fruits. Such fruits should be packed in shallow zases. and placed in a cold store as soon as possible. after picking. 


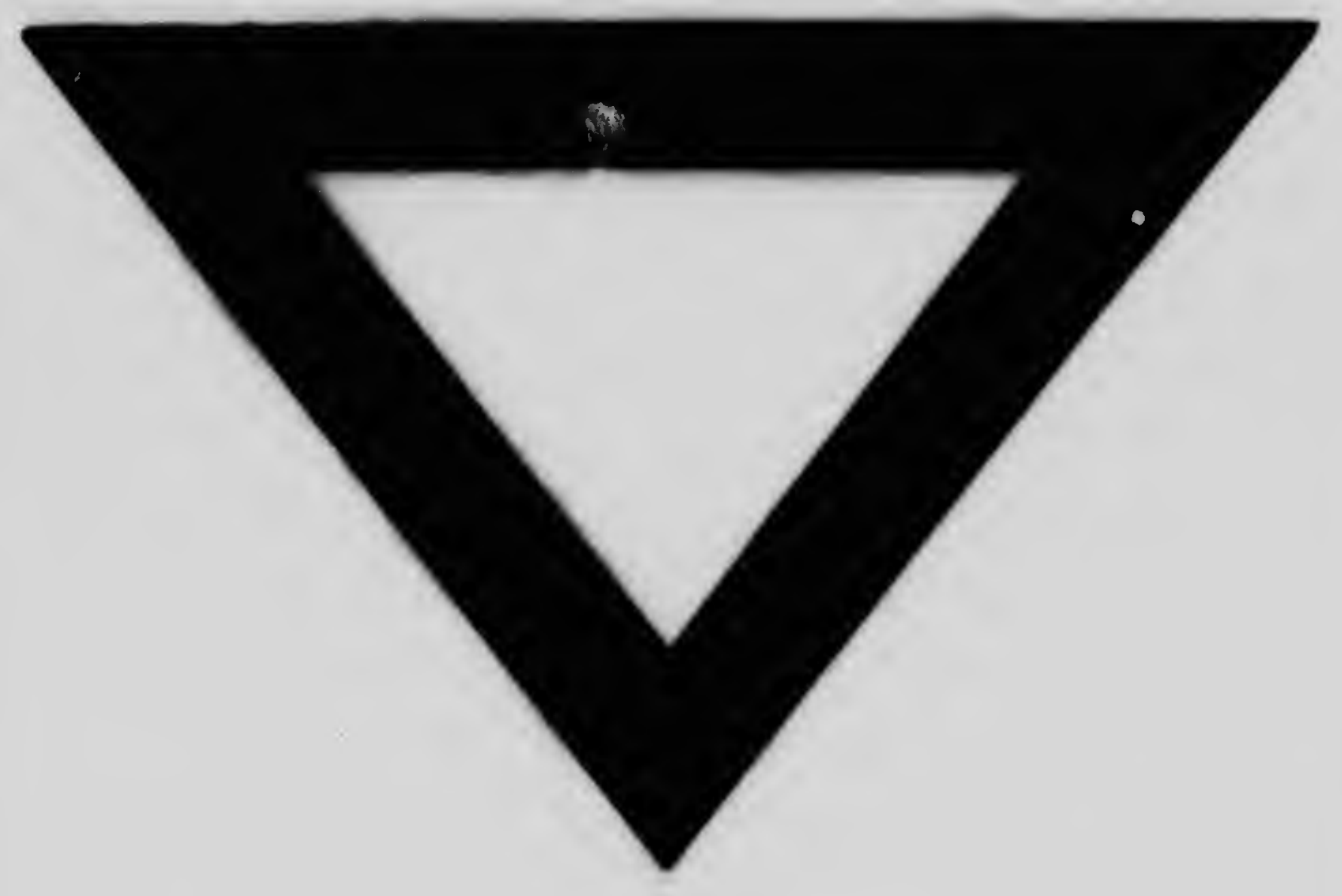

